\title{
The biosemiotics of Aldo Leopold
}

\author{
Rebecca C. Potter \\ Department of English, University of Dayton \\ 300 College Park, Dayton, OH, USA 45469 \\ e-mail: rpotter1@udayton.edu
}

\begin{abstract}
Responding to Jean-Claude Gens' article, “Uexküll's Kompositionslehre and Leopold's 'land ethic' in dialogue", which appeared in Sign Systems Studies in 2013, the article further develops a direct connection between Aldo Leopold's approach to ecology and Jakob von Uexküll's umwelt theory. The connection between Uexküll and Leopold is especially evident in Leopold's descriptions of animal behaviour that he presents in the first part of his seminal work, A Sand County Almanac. In this work specifically, Leopold illustrates the biosemiotic processes described by Uexküll, and does so with a purpose: to reshape our understanding of the biotic community as a place of semiotic interaction.
\end{abstract}

Keywords: Aldo Leopold; Jakob von Uexküll; Jean-Claude Gens; biosemiotics; translation; umwelt

Jean-Claude Gens has recently argued in this journal for more deeply considering the intellectual affinity between Jakob von Uexküll's umwelt theory and Aldo Leopold's land ethic. Aldo Leopold and Jakob von Uexküll share the perspective that objects in the natural world possess a subjective meaning-making quality. Gens connects Uexküll's interest in the "meaningful dimension of how the living apprehend their umwelt" with Leopold's understanding of a biotic community wherein each member of that community (plants, animals, soil, etc) is meaningful to it (Gens 2013). For Uexküll, the biologist witnesses how organisms perceive and understand objects in their umwelten; for Leopold, the ecologist finds meaning-making activities generated through the interconnected processes that define a biotic community. Gens further connects Uexküll and Leopold through their shared interest in the Kantian concept of the numenon; Leopold discovered the concept indirectly through reading work by the vitalist philosopher Piotr Ouspensky (see Ouspensky 2004[1912]), whereas Uexküll was more directly familiar with Kant's philosophical writings on the numenon. By understanding this connection more deeply, Gens argues, we can extend Uexküll's doctrine of meaning into the realm of ethics and use Uexküll's umwelt theory to deepen our understanding of Leopold's land ethic. The argument is an important one, mapping out a common ground for both thinkers that intersects with the field of biosemiotics. 
I would extend the argument further. Namely, Uexküll and Leopold adopt the same approach in understanding how organisms interact in a given environment. Leopold's affinity with Uexküll's work, which has been primary to the field of biosemiotics, is deeper than a shared interest in Kant's numenon, and that Leopold's approach to ecology places him squarely in the tradition of biosemiotics. The connection between Uexküll and Leopold is even more directly evident in Leopold's seminal work, $A$ Sand County Almanac (Leopold 1987[1949]), and may be more central to Leopold's ecological epistemology than any philosopher or critic has yet realized.

\section{Leopold's biosemiotics: The influence of Uexküll and Peirce}

Much of the formative work in biosemiotics is based in large part on the semiotics of Charles Sanders Peirce, and the biological contributions of Jakob von Uexküll. ${ }^{1}$ Though Aldo Leopold illustrates a biosemiotic approach to studying nature in $A$ Sand County Almanac, the question remains to what degree - if any - Leopold would have been familiar with the ideas and writings of Peirce, Jakob von Uexküll or the latter's umwelt theory. Leopold does not reveal any direct influence from either Peirce or Uexküll in his own writings, which are copious and spread across his adult life. Because of this, it is hard to determine whether Leopold came across Uexküll's work directly, but there is some evidence that shows he likely knew of it, and may have read Uexküll's Umweltlehre and other works. One of the few copies of that work to be found in the United States during Leopold's lifetime was held in the University of Wisconsin library where Leopold taught. ${ }^{2}$ Leopold grew up in a German-speaking family and read German fluently, so the fact that Uexküll's works were not translated would not have been a hindrance. But Leopold would have also likely learned of Uexküll's umwelt theory during his five-month sojourn in Germany in 1935. The trip brought him in contact with at least two people who could have aroused a curiosity in

1 Thomas Sebeok and Thure von Uexküll (Jakob von Uexküll's son) have been the most prominent developers of this connection. Noting that Uexküll had no knowledge of Peirce, Saussure or general linguistics, semiotics explains the sign processes his umwelt theory describes: "As soon as it is clear to us that Umwelt-research explores the sign-processes that govern the behavior of living subjects even of cells, we can see that in fact there is a genuine analogy between linguistic and biological laws of formation that in the final instance removes the distinction between the human and the natural sciences. [...] Therefore, we may compare concepts such as system, structure, unity, etc., which the linguistic sciences provide, with the concepts of Umwelt theory because the linguistic concepts illustrate the concepts of Umwelt theory" (Uexküll, T. v. 1982: 8).

2 The University of Wisconsin-Madison's libraries held a number of Uexküll's works, including Die Lebenslehre (1930), Biologische Briefe an eine Dame (1920), and the second edition of Theoretische Biologie (1928). 
Uexküll's work. Franz Heske guided the group of American foresters and he singled out Leopold explicitly to accompany him on various trips to forest estates precisely because of the latter's fluency in German. Heske was an avid promoter of the Dauerwald (sustainable forest) method of forest management, which quickly gained Leopold's interest (Leopold 1935; 1936a). They shared another connection through Gifford Pinchot, whom Leopold knew as the former director of the Yale School of Forestry, and as his boss when Leopold worked for the U. S. Forest Service. Heske was a student of Dietrich Brandis, who in turn was Gifford Pinchot's teacher and mentor early in Pinchot's career (Miller 2001). As a young man, Heske worked on the very forest management projects in India for which Brandis was famous, and which figured prominently in Leopold's study of forest management when a student at Yale.

That connection to Pinchot would have also made Leopold familiar with Peirce's ideas when he was a student in Yale University's School of Forestry founded by Pinchot. The Pinchots were neighbours and good friends of Peirce and his wife in Milford, New York. Leopold may have met Peirce at Grey Haven, as it was also the location of the School of Forestry's summer school, where Leopold spent the summer in 1907 (Miller 2001). Peirce was also interested in the mission of the newly established School of Forestry, and had an impact on the younger Pinchot's thoughts concerning forest management (Fisch 1982). If claims are made concerning the influence of Peirce on Leopold's thought, they reference the impact of pragmatism (Minteer, Pyne 2013; Norton 2011; Callicott et. al. 2009). However, this debate ignores the significance of Peirce's work on semiotics, which I would argue had an impact on Pinchot's conception of forest management, and his interest in seeing environmental impacts as signs or symptoms of biotic health ${ }^{3}$

However, it is Heske's student, Arnold Freiherr von Vietinghoff-Riesch, who likely provides the more direct connection between Uexküll's work and its influence upon Leopold. ${ }^{4}$ Vietinghoff-Riesch was a falconer, an engaged ornithologist, and the baron of a large family estate near Tharandt. Heske took Leopold to VietinghoffRiesch's estate in 1935, and it was there that Leopold was introduced to falconry.

3 A semiotic approach to forestry, i.e. reading the forest for signs or symptoms of a disruption permeates Pinchot's early books on forest management (cf. Pinchot 1905). The connection between Peirce, a friend and mentor to Pinchot and the semiotic aspects of Pinchot's development of forestry science is a heretofore inadequately researched topic, and beyond the scope of this paper.

4 Uexküll (1940: 2) shows no tolerance for either the "Mechanists" or the "Behaviourists", both of whom he considers guilty of tremendous over-simplification in their scientific approach: "one can easily say that as experimental science becomes increasingly more complex, thought becomes increasingly simple and superficial" (my translation, R. P.) [So kann man wohl sagen, dass das Experimentieren immer komplizierter, das Denken aber immer einfacher und billiger geworden ist]. For a full critique of mechanistic science see Driesch's Biologische Probleme höherer Ordnung (1941). 
The two men struck up a friendship that lasted for over a decade, exchanging their ideas concerning ecological forestry. Vietinghoff-Riesch had just completed his Habilitation under Heske's direction, entitled Naturschutz, and later gave Leopold a copy. The work emphatically defends the Dauerwald concept, focusing on the importance of diverse plants and animals for maintaining forest health, which are usually considered insignificant or even noxious.

While Uexküll is not a direct source for Vietinghoff-Riesch's Naturschutz, in that work Vietinghoff-Riesch describes an ecological system as a network wherein each organism performs a necessary function that suits it, and shows a similar interest in the semiotic activities of animals (Vietinghoff-Riesch 1936a: 118-128; 1936b). He sought to show how "pests" such as raptors, vermin and weeds are necessary to an ecosystem because of the ecological benefit that their function provides to a biotic community (Gemeinschaft), termed a role they each play. For Vietinghoff-Riesch, the interactions between these species enrich the diversity of the biotic community, which maintains its health and ensures its productivity (Steinsiek 2009: 255). Like Leopold in A Sand County Almanac, Vietinghoff-Riesch portrays fauna as various community members, each acting and interacting in its environment, also using terms such as plant or animal "sociology" and "Biologie des Waldes" (VietinghoffRiesch 1936b: 118; 1940: 11-17). Leopold was so impressed with Vietinghoff-Riesch's approach to ecology that upon his return to the United States he encouraged the Oberlaender Trust to translate and publish Naturschutz for an American audience (Leopold 1936b . $^{6}$

Kalevi Kull articulates a paradigmatic distinction in biosemiotics, which lies in a resistance to a purely mechanistic approach that discounts subjectivity. For Kull, this opposition is a continuation of a general theoretical divide stretching back to the division between Kepler and Newton, Goethe and Kant, and Baer and Darwin (Kull 1999). Uexküll vociferously rejected the mechanistic trend in evolutionary biology promoted by his contemporary Ernst Haeckel, while Vietinghoff-Riesch (1936a: 120122) places himself in the vitalist camp. Leopold's enthusiasm in Vietinghoff-Riesch's work further indicates the affinity between his approach to ecology as a discipline and the vitalism that informs Uexküll's umwelt theory. Leopold was exposed to a discussion among foresters and natural scientists emerging from a vitalist as

\footnotetext{
Leopold 1936b was accessed at http://images.library.wisc.edu/AldoLeopold/EFacs/ ALWildEcol/ALWildEcolO-R/reference/aldoleopold.alwildecolor.i0001.pdf.

6 In his autobiography, Letzter Herr auf Neschwitz, Vietinghoff-Riesch (2002[1952]: 211-212) briefly discusses these visits from American foresters, and especially the reaction of the owners of large lumber companies when visiting his small-scale, 'kahlschlaglosen' forest. Leopold's fluency in German facilitated their friendship, and Vietinghoff-Riesch visited the Leopolds after the war.
} 
opposed to mechanistic approach to the scientific study of nature. Gens finds in this connection a link to Uexküll's thought, and Leopold's interest in VietinghoffRiesch's work that is firmly placed in the same school of thought bears this out. What emerged was Leopold's development of an environmental ethics that regards the nonhuman other as an intentional subject.

\section{Reading nature: An ecology of semiosis}

However, the most relevant way to observe how Leopold illustrates the biosemiotic processes described by Uexküll, appears in A Sand County Almanac. Leopold does so with a purpose: to reshape our very understanding of the biotic community as a place of semiotic interaction.

Biosemiotics challenges the assumption that only human beings understand and interact with their world through communication. Jesper Hoffmeyer (2008: 4) provides a succinct definition: "According to the biosemiotic perspective, living nature is understood as essentially driven by, or actually consisting of semiosis, that is to say, processes of sign relations and their signification - or function - in the biological processes of life". Semiotic processes (semiosis) refers to the neurobiological capacity to consistently produce and comprehend perceptual input through a codifiable process (Sebeok, Danesi 2000: 5, 161). Leopold illustrates the communicative behaviour of living creatures in a shared environment, showing how organisms make meaning of their world. He then makes the case that possessing an understanding those communicative behaviours benefits the ecologist and the land-owner alike. And while fundamentally separate and different from the semiotic complexity exhibited in human communities, semiotic practices of animals - and plants - open up a rich world of interactions the ecologist can observe, puzzle over, and enjoy.

A Sand County Almanac is divided into three parts: In the first part, the almanac section of the book, Leopold describes what he observes on and around "the Shack", a run-down piece of property he purchased through a bank foreclosure and was attempting to restore (Flader 1987). In the second part, he narrates specific moments in his life that shaped his ecological thinking; Leopold's renowned essay "Thinking like a mountain" is found in this section. The third part contains a series of more philosophical essays in which Leopold grapples with central problems facing environmental conservation, and considers those problems from political, aesthetic, and ethical perspectives; this section concludes with his essay "The land ethic", which has been used by philosophers such as Baird Callicott and others to develop a nonanthropocentric environmental ethic (Callicott 1999; Gens 2013). 
The first part - the almanac section of A Sand County Almanac - has received the least amount of critical interest, and yet is the most detailed in revealing Leopold's practice as an ecologist. ${ }^{7}$ The various sketches of animal activity and plant functions in the first part of $A$ Sand County Almanac illustrate the ecologist at work, attempting to interpret the myriad semiotic processes he observes. It opens with its narrator (Leopold) following the tracks of a skunk. It is January, and a warm spell followed by a snow thaw, typical for that time of year in Wisconsin, has triggered a variety of natural activities, such as the nocturnal sojourn of a skunk that would normally be in hibernation. Leopold (1987[1949]: 3) writes:

Each year, after the midwinter blizzards, there comes a night of thaw when the tinkle of dripping water is heard in the land. It brings strange stirrings, not only to creatures abed for the night, but to some who have been asleep for the winter. The hibernating skunk, curled up in his deep den, uncurls himself and ventures forth to prowl the wet world, dragging his belly in the snow. His track marks one of the earliest datable events in that cycle of beginnings and ceasings, which we call a year.

Notably, the presence of a skunk track precipitated by the January thaw is a repeatable occurrence that marks a mid-winter transition. On one level, Leopold is illustrating to his reader what this track signifies or means to him as a "literate" reader of the natural world who can read objects such as the skunk track as "signs" (Ryden 2008; Talmadge 1987). He thus models for his own human reader how to become literate in another kind of reading a phenomenon in the natural world - like the skunk track as a "mark" or sign that announces the beginning of the year.

Rydan and Tallmadge have effectively illustrated how extensively Leopold uses the act of reading as a metaphor for the practice of a land steward or ecologist, which this passage illustrates. Yet by focusing on the ecologist as a literate reader of nature, we miss Leopold's characterization of the skunk as a subject deriving meaning from the changes it perceives around it. In attempting to discover what stimulates the skunk's journey, wondering what "this corpulent fellow" (Leopold 1987[1949]: 3) could have been up to on a January night, Leopold (1987[1949]: 5) constructs how the skunk senses and responds to its world, obviously trying to create the subjective world of the skunk:

7 Finch (1987: xix) characteristically reflects the view that Part I is the least notable of the three sections when he writes in his introduction to the Oxford edition of A Sand County Almanac: "If A Sand County Almanac had included only the shack essays of Part I, it would have been a slim, minor classic of graceful and perceptive natural-history narratives". Instead, due to the essays in Parts II and III, "no other single book of American nature writing - with the exception of Walden - has achieved such lasting stature" (Finch 1987: xv). 
The skunk track leads on, showing no interest in possible food, and no concern over the rompings or retributions of his neighbors. I wonder what he has in his mind; what got him out of bed? Can one impute romantic motives to this corpulent fellow, dragging his ample beltline through the slush? Finally the track enters a pile of driftwood, and does not emerge. I hear the tinkle of dripping water among the logs, and I fancy the skunk hears it too. I turn homeward, still wondering.

Leopold seeks to understand the signs that have meaning to a skunk and thus delineate its world. What impulse spurred the skunk's actions? How are the perceived change in temperature and the skunk's sojourn connected? As Leopold asks, what did the skunk have "in his mind"? The mystery remains, however, which Leopold then turns into a narrative opportunity to reveal how the semiotic processes found in nature's text remaining untranslated.

Leopold's ecological practice is reflected again when, while following the skunk track, he spots a meadow mouse crossing in front of him. He asks himself why the mouse would be abroad in daylight? Of course, on one level this illustrates how an ecologist attentively observes the biotic activity around him. What follows, however, is a biosemiotic investigation into the communicative properties of interaction that delineate the umwelt of the mouse. Leopold first extrapolates how the mouse perceives the snowmelt: The melting snow has wreaked havoc upon its domain, which leads to the rash action of exposing itself to predators, "[p]robably because he [the mouse] feels grieved about the thaw". Leopold further extrapolates how the mouse may be perceiving his umwelt: "Today his maze of secret tunnels laboriously chewed through the matted grass under the snow, are tunnels no more, but only paths exposed to public view and ridicule". Leopold then configures perception as the locus for the mouse-subject to make meaning of its world: "The mouse is a sober citizen who knows that grass grows in order that mice may store it as underground haystacks, and that snow falls in order that mice may build subways from stack to stack: supply, demand, and transport all neatly organized" (Leopold 1987: 4). That "knowing" is derived from the perceptive faculties of the mouse, which in turn determine the internal formation of its particular umwelt.

Similarly, Uexküll argues that any living organism capable of perceiving the external world in which it functions (its umwelt) also exhibits different modelling strategies for processing and monitoring sensory perception, depending on the organism's biological and physiological capabilities, what he called its Innenwelt (all that is internal to it). Perception is fundamentally shaped by the mouse's physiology and biological programming, the particular Innenwelt of a mouse, determined as it is by its anatomy, the complexity of its brain and nervous system, its sensory capacities, it experiential processes that result from function in a given environment, to name just a few of the complex web of factors involved in semiosis. 
An organism's umwelt is a world of signs perceived and embodied with meaning through its Innenwelt. In this sense, a particular umwelt constitutes a system of responses to the objects that the organism perceives, while at the same time those responses reveal what meaning those perceived objects hold for that particular creature. Objects gain or change meaning through an organism's interaction with them, which in turn creates experience that can shape how an organism/subject understands a sign/object (Uexküll, J. v. 1913). The mouse sees the snow thaw within the frame of meaning that emerges out of instinctual and environmentally determined practices and habits of the mouse. These interactions reflect how the mouse perceives an object as a sign, in other words, as an object with a meaning.

Uexküll's umwelt theory is based on the premise that meaning fundamentally captures the development and function of an organism (Uexküll, J. v. 1982: 37). It is only by studying these interactions that we can determine causal connections between physiognomy, activity and biotic function in a systemic way. A search for understanding these connections is structuring Leopold's observations as he follows the skunk, observes the mouse, and then, a few moments later, sees a rough-legged hawk that makes a raptor's dive into the snow. Leopold again asks what in its umwelt triggers the hawk's dive? The hawk remains on the ground, and Leopold surmises that it caught a mouse: "He does not rise again, so I am sure he has caught, and is now eating, some worried mouse-engineer who could not wait until night to inspect the damage to his well-ordered world" (Leopold 1987: 4). Leopold then contrasts how grass and snow mean something different for the mouse and the hawk, emphasizing both their subjective responses to the same phenomenon, the melted snow. Their activity is explained in a way that correlates with Uexküll's umwelt theory: as a schematic relationship between the subject's sensual organs (Merkorgane) and the objects that a subject perceives, which function as signs. Physical action is predicated upon sensual perception.

Leopold captures the separation of and interconnection between each subject's umwelten in this interplay between mouse and hawk. What is striking, however, is the similarity between Leopold's descriptions of biotic activity and Uexküll's descriptions of biotic activity, both highly emphasizing semiosis. Leopold's illustrations capture Uexküll's concept of umwelten, which consists of those objects significant to a specific subject (Uexküll, J. v. 1980: 136). For example, Uexküll writes, “The meaning of the forest is multiplied a thousand fold if its relationships are extended to animals and not limited to human beings", and to illustrate his point he examines the many ways a blooming wildflower is perceived by four different subjects: a girl, an ant, a cicada-larva, and a cow. Uexküll uses the example to illustrate what he calls the relationship-network of the four umwelten, which is established by the role of each subject: 
(1) In the Umwelt of a girl picking flowers, who gathers herself a bunch of colorful flowers she uses to adorn her bodice;

(2) In the Umwelt of an ant, which uses the regular design of the stem-surface as the ideal path in order to reach its food-area in the flower petals;

(3) In the Umwelt of a cicada-larva, which bores into the sap-paths of the stem and uses it to extract the sap in order to construct the liquid walls of its airy house;

(4) In the Umwelt of a cow, which grasps the stems and the flowers in order to push them into its wide mouth and utilizes them as fodder.

Just as the hawk and mouse hold different meanings for snow, all of these subjects have their own particular meaning for a flower based on its use to them. The girl uses flowers as an adornment, because she perceives flowers as colourful and aesthetically pleasing. We see the same interaction in the ant, the cicada-larva and the cow:

The picking of the flower transforms it into an ornamental object in the girl's world. Walking along the stem changes the stem into a path in the ant's world, and when the cicada-larva pierces the stem, it is transformed into a source for building material. By grazing, the cow transforms the flower stem into wholesome fodder.

Every action, therefore, that consists of perception and operation imprints its meaning on the meaningless object and thereby makes it into a subject-related meaning-carrier in the respective Umwelt. (Uexküll, J. v. 1982: 29-31)

Use lies at the centre of these different meanings; grass grows for the mouse's grain storage, and snow melts so that hawks can catch mice. Use is thus concomitant to function. In other words, snow has a use for the mouse in providing cover from the hawk because, from the perspective of the mouse, snow functions as cover from predators. And this function is embedded in how the mouse perceives snow - as an effective shelter from hawks - which creates a meaning particular to the mouse: "To the mouse snow means freedom from want and fear", while "the rough-leg has no opinion why grass grows, but he is well aware that snow melts in order that hawks may again catch mice. He came down out of the Arctic in the hope of thaws, for to him a thaw means freedom from want and fear" (Leopold 1987: 4). Leopold thus presents in this comparison a triadic semiosis wherein snow is an indexical sign interpreted consistently but differently by two subjects.

This comparison of the mouse and hawk illustrates a model for biological interaction that is in line with the umwelt theory of Uexküll in a number of ways. It shares with the umwelt theory the position that an organism is an autonomous subject possessing certain capabilities of perception; in complex organisms perception is a neural activity, and in simpler ones, usually a chemical one. An organism perceives 
the material world in which it lives, and then orders those perceptions in a way that gives them a meaning, or significance. What a specific organism "understands", what is meaningful or significant to it, is indeed primarily based on its physiology.

This act of modelling for his reader how to actively interpret objects in nature as signs reveals Leopold's engagement with semiotics in his approach to ecology. He incorporates a way of analysing animal interactions that illustrates the semiotic processes of active relations between organisms and their environment. For the purpose of diagnosis, the one-time occurrence holds little interest to the ecologist diagnosing tell-tale signs of change. It is only through recurrent manifestation that an observation becomes symptomatic and predicative of a certain condition. That aspect of ecology is poignantly expressed in "The round river: A parable" where Leopold (1991: 165) writes:

One of the penalties of an ecological education is that one lives alone in a world of wounds. Much of the damage inflicted on land is quite invisible to laymen. An ecologist must either harden his shell and make believe that the consequences of science are none of his business, or he must be the doctor who sees the marks of death in a community that believes itself well and does not want to be told otherwise. $^{8}$

Leopold shows his reader how he attempts to translate the semiotic activities within a land community that present themselves as consistent marks to be read and interpreted. This is the almanac quality of $A$ Sand County Almanac, which also provides a model for another aspect of the ecologist's work, to recognize the signs of a functioning ecosystem, so that deviations or symptoms of change can be spotted, and hopefully cured.

\section{The ecologist as translator: The language of a biotic community}

Reconstructing a subjectivity for individual members of a biotic community (skunk, mouse, hawk) is of particular importance to Leopold's study of nature because it indicates how semiotic processes provide insight into animal behaviour in a given

\footnotetext{
8 An ecologist as diagnostic physician has a longer history, dating to 19th-century European forestry, and promoted by the founder of the Yale School of Forestry, Gifford Pinchot. There is some evidence that C. S. Peirce, a friend of Pinchot and his family, also may have influenced how Pinchot envisioned the work of the forester that he articulates in The Training of a Forester (Pinchot 1917). The concept of a symptom as a sign for change or disease in a "body" stretches back to Hippocrates (who coined the term 'semiotik'), and continues to be a part of medical practice in various ways (see Ots 1991: 283-5; Sebeok 1984: 37-42).
} 
environment and is representative of a working ecosystem. In this way Leopold is interested in just that biosemiotic activity which Giorgio Prodi (1989: 95) calls reading and which is somewhat different from the "reading" discussed above. Leopold's own depiction of the ecologist-as-diagnostician stresses reading the signs of nature as symptomatic. Yet, while he does practice those types of semiotic activities, he goes further in trying to figure out how the non-human members of the biotic community are reading their own worlds.

For example, in the final chapter of the almanac section, "December", Leopold engages in this very question concerning how the animals living on his property perceive their place. What is their geography? He distinguishes how their actions reveal an answer:

The wild things that live on my farm are reluctant to tell me, in so many words, how much of my township is included within their daily or nightly beat. I am curious about this, for it gives me the ratio between the size of their universe and the size of mine, and it conveniently begs the much more important question, who is the more thoroughly acquainted with the world in which he lives?

Like people, my animals frequently disclose by their actions what they decline to divulge in words. (Leopold 1987: 78)

Leopold then presents different scenarios that reveal the home range of a variety of animals: a jack rabbit, chickadees, grouse, and deer that all reside on "The Shack". When his dog flushes a jack rabbit while Leopold is chopping wood, he notices how the rabbit "makes a beeline for a woodpile a quarter-mile distant, where he ducks between two corded stacks, a safe gunshot ahead of his pursuer". Seeing the jack rabbit get away Leopold observes, "The little episode tells me that this rabbit is familiar with all of the ground between his bed in the meadow and his blitz-cellar under the woodpile. How else the beeline? This rabbit's home range is at least a quarter-mile in extent". He then compares the rabbit's beeline to the nocturnal route of three deer that he constructs by retracing their tracks; they leave their beds located in a willow thicket on a sandbar and cut across Leopold's property, then eat the waste corn in a neighbour's cornfield, then loop back to the sand bar pawing at some tufts of grass en route and drinking from a spring. "My picture of the night's routine is complete" Leopold writes, "The overall distance from bed to breakfast is a mile". Observing the signs of grouse activity in winter he discovers that rather than wade through soft snow, the birds walk along fallen logs to a patch of frozen night shade berries then fly to their roosts, "and the range was half a mile across" (Leopold 1987[1949]: 78-81).

In each case, the animal in question reveals an intentional action based on a subjective understanding of its umwelt, what Leopold at this juncture calls its universe or its world. The woodpile is an object in the rabbit's umwelt that has a particular 
meaning based on its use; it provides shelter from a predator. The deer follow a determined path based on their knowledge of their specific home range, and so do the grouse. In semiotic terms, they reveal a level of literacy derived from being schooled in survival. When the ecologist can penetrate the subjective world of the rabbit by figuring out what objects have meaning for it, he is translating the rabbit's "book", which is how Leopold describes the process at the end of the segment: "Every farm is a textbook on animal ecology; woodsmanship is the translation of the book" (Leopold 1987[1949]: 81). Translation, however, indicates that the text (what is being translated) is the umwelt of the rabbit, deer, grouse, and the semioses generated in those umwelten.

The ongoing and enjoyable work of translating brings its own insights. Ecology is the task of the translator, working with the signs she has to determine what holds meaning for another (non-human) subject, and what that meaning might be. Uexküll casts the task of the translator in a similar vein Uexküll argues observation of the natural world requires the human observer to seek out two aspects of any interaction between an organism and its umwelt. First is the task of determining the perceptive attributes of that organism, what it perceives and how those perceptions manifest in its Innenwelt. Then the scientist can decipher the myriad of meaning-making activities within a biotic community.

Translation recasts a common understanding of Leopold's ecological practice as exhibited in the almanac in two key ways. First, it heightens awareness of how consistent Leopold's method is with biosemiotics. Second, it asks us to rethink these sketches commonly interpreted as entertaining characterizations, and therefore anthropomorphic in quality, and to reexamine them in light of a more radical understanding of autonomy and subjectivity extended to the non-human - one that is informed by biosemiotics.

The way an organism experiences its umwelt also reveals its abilities and habits, and when found in a narrative form, such as is the case in A Sand County Almanac, its character. Character is a contentious term in this context. In narrative, animal behaviours are habitually understood as expressions of character, and it would be easy to read Leopold's description of the mouse, the hawk, and the skunk in this light. The mouse is acting mouse-like, and the hawk, hawk-like, just as a villain in a fairy tale acts villainously and a hero, heroically. But what constructs the mouselike or hawk-like character? Jesper Hoffmeyer (2008: xiii) asks an intriguing question that is also central to Leopold's interest in the skunk: "How can we be so sure that these animals themselves - as environmentally situated organisms of blood, flesh, and brain - take no creative part in their own behavior?". While not refuting the evolutionary explanation for much of animal behaviour, Hoffmeyer articulates an assumption of Uexküll's: living creatures, especially those with more complex neural systems, exhibit behaviours that are not adequately described in a purely mechanistic 
fashion. Animals exhibit intentions, which are shaped by their experience of the environment in which they live. Hoffmeyer uses a term that aptly describes Leopold's approach to an ecological understanding of nature, that of "natural play" (as opposed to "natural selection") discoverable in a given biotic community. The play between species can be seen in the myriad of activities carried out continually within that striving community. According to Hoffmeyer (2008: xiv), "Making scientifically responsible sense of this "striving" is one of the challenges that the emerging scientific field called biosemiotics sets out to accept".

Biosemiotics posits that an organism's capability of semiosis necessitates an intentional act. Clearly, Leopold illustrates how the animals he observes show intention, and how that intention is seen in the way the objects are signs in their subjective worlds. Yet is it too much to assume intentional striving in the skunk? One could reply that any narrative will necessitate intentions in its characters. Once people use human language to describe the natural world - once the things in that world become actors - intentions among those actors in that world will magically appear. In other words, a thing cannot be a subject or character unless it exhibits intention, or inversely, once a person articulates a thing as a character it will have an intention. When a white blood cell is described as attacking a virus, or a hawk hunting for a mouse, intent is manifest in the blood cell or in the hawk. This is a transitive limitation of descriptive narrative that makes any discussion of semiotics in any subject other than the human subject very difficult.

Leopold does seem to make an attempt to overcome this difficulty by contrasting the imbedded meaning the same object holds for two different animals, and how various animals (including Leopold himself) perceive and understand the same space. There is no shared communication enabled by place, which is inherent to an anthropomorphic characterization; rabbit, grouse, skunk, and man are all subjectively contained by the semiotic process of their subjective worlds. The mouse and hawk do not "speak" to each other through their actions. In fact, it is the limitation of the mouse's umwelt that puts it in danger of the hawk; limited to its mouse world, the mouse cannot perceive what snowmelt means for the hawk - a great opportunity to catch a mouse! ${ }^{9}$ Completely outside of this transaction between mouse and hawk is the ecologist, a translator in this case, whose involvement is only through the act of description. However, the semiotic processes he interprets come from the actions of

\footnotetext{
9 Weber clarifies this issue in light of Uexküll's Umwelt Theory, emphasizing how Uexküll was certain that the natural world consisted of individual organisms, each in its own "soap bubble", yet interconnected through a complex web of interactions that define their perceptions of that world (see Weber 2003: 97; see also Uexküll, J. v. 1926: 42). I would argue that the shared focus on what the soap bubble of each organism contains also enables both Leopold and Uexküll to redefine the subject in such a way as to allow for the subject's intrinsic value
} 
the mouse and the hawk, respectively, each functioning within their respective umwelt. Even when conveyed through a human narrator, intention originates in them.

Yet is not the ecologists' translation subject to the human a propensity to use metaphors, in this case metaphors of communication, speaking, reading, performing, in order to describe animal behaviour better to a lay audience ${ }^{20}$ By using terms such as 'meaning' or 'performance' to explain animal interactions, does Leopold engage in just another type of anthropomorphic characterization?

Answering yes to these questions would still point to how Leopold depicts a particularly situated way of seeing, but the view is necessarily located in the human observer. It would assume that the activities of other organisms remain a mystery to the human subject, and this gulf can only be bridged by symbolic language. Metaphor would be the tool for building that bridge, while creating those metaphors would constitute a practice in aesthetics rather than scientific observation. There is some evidence in Leopold's work to substantiate this position. Leopold uses slave ownership and liberation as analogies to preface his call for an ethic extended to non-human nature (Leopold 1987: 201-3). In the almanac section he constructs an elaborate metaphor of an ancient oak tree as a chronicler of past events (Leopold 1987: 6-18). The geese engage in international commerce, and the crane is a reminder of a natural history that stretches far longer than our human one (Leopold 1987: 23, 96).

Yet, while Leopold clearly loves to spin metaphors out of the fabric of what he observes, he also carefully constructs depictions of animal activity as iconic or indexical semiotic processes that are only made symbolic when viewed through the human lens. In this sense Leopold tacitly models what Susanne Langer (1948) referred to as 'abstractive seeing', using the image schemas he derives from ecological observation to create a more complex and meaningful language for reading nature. The members of the biotic community that populate the Shack engage in life activities that show intention and interpretation as distinctly different from the symbolic language of human beings. And rather than enfold animal behaviour into metaphor, Leopold's deliberate and highly constructed use of metaphor effectively separates the human observer from the biotic activities around him. Metaphor functions then as a way of distinguishing his own human semiotic processes as narrator from the non-human semiotic processes he describes occurring among non-human subjects.

10 This is a challenge facing the field of biosemiotics, more aware than most disciplines of the power of metaphor to shape meaning. Both Thure von Uexküll (1982) and Hoffmeyer (2008) make the point that, as Hoffmeyer (2008: xv) states, "biosemiotics is often dismissed by scholars - not least, those from the humanities - who fundamentally misconceive the project as an attempt to project anthropomorphic features upon an existing world". This tendency to read Leopold's descriptions of animal behaviour as anthropomorphic characterization is likely why the biosemiotic aspect of his observations has gone unnoticed. 
There is still a great amount of work to be done in connecting early twentiethcentury thought in forestry and ecology to the field of biosemiotics. Examining Aldo Leopold's descriptions of animal behaviour is a first step in showing how not only his practice as an ecologist, but also his philosophical conviction that members of a biotic community are subjects capable of intentionality are in line with Jakob von Uexküll's umwelt theory and subsequent work in biosemiotics. Sense and intention seem to necessitate semiosic processes that indicate that an organism is a subject capable of intention. Many of Leopold's intellectual pursuits in A Sand County Almanac are aimed at finding out what not only the intention, but also what the intentional object in an organism's umwelt could be. Manifesting an intentional object is for Leopold an act of interpretation, it places the iconic and indexical signs sensed by organisms in the natural world into a symbolic contextualized relationship that facilitates ecological understanding. As such, determining the umwelt of an organism is an act of translating, and takes as its basis the inseparability between a non-human subject and its world.

Gens (2013: 76) points out that, "the holism found in Uexküll's and Leopold's ideologies has a direct effect on the way they conceive the relationship linking humanity to nature", which demands that we broaden our sense of what it means to belong to a community. Generally in clarifying this notion of community philosophy has focused on the concept of belonging, citizenship, and value. A biosemiotic analysis of Uexküll and Leopold in tandem uncovers and fruitful, and perhaps more definitive, understanding of community in this context: as the interconnective web of semiotic practices engaged by each subject in a certain biotic sphere; in other words, as a place of meaning.

\section{References}

Callicott, J. Baird; Grove-Fanning, William; Rowland, Jennifer et. al. 2009. Was Aldo Leopold a pragmatist? Rescuing Leopold from the imagination of Bryan Norton. Environmental Values 18(4): 453-486.

- 1999. Beyond the Land Ethic: More Essays in Environmental Philosophy. New York: State University of New York Press.

Driesch, Hans 1941. Biologische Probleme höherer Ordnung. Bios 11. Leipzig: Verlag von Johann Ambrosius Barth.

Finch, Robert 1987. Introduction. In: Leopold, Aldo. A Sand County Almanac, And Sketches Here and There. Oxford: Oxford University Press.

Fisch, Max 1982. Peirce's place in American life. Historia Mathematica 9(3): 265-289.

Flader, Susan 1987. Aldo Leopold's Sand Country. In: A Companion to A Sand County Almanac: Interpretive and Critical Essays (Callicott, Baird, ed.). Madison: University of Wisconsin Press, 40-62.

Gens, Jean-Claude 2013. Uexküll's Kompositionslehre and Leopold's "land ethic" in dialogue. On the concept of meaning. Sign Systems Studies 41(1): 69-81. 
Hoffmeyer, Jesper 2008. Biosemiotics: An Examination into the Signs of Life and the Life of Signs. Scranton: University of Scranton Press.

Kull, Kalevi 1999. Umwelt and Evolution: From Uexküll to Post-Darwinism. In: Taborsky, Edwina (ed.), Semiosis. Evolution. Energy: Towards a Reconceptualization of the Sign. (BBS Neue Folge 3.) Aachen: Shaker Verlag.

Langer, Susanne K. 1948. Philosophy in a New Key. Cambridge: Harvard University Press.

Leopold, Aldo 1935. Notes on wildlife conservation in Germany. Game Research News Letter 6/7 (Sept./Oct.): 1-3.

- 1936a. Deer and Dauerwald in Germany 1: History. Journal of Forestry 34(4): 366-375.

- 1936b. Letter to Mr. Wilbur K. Thomas. Oberlaender Trust. November 27, 1936. Aldo Leopold Digital Archive MS: Leopold, Aldo/Organizations, Committees: O-R; Oberlaender Trust.

- 1987[1949]. A Sand County Almanac, And Sketches Here and There. Oxford: Oxford University Press.

- 1991. The River of the Mother of God and Other Essays. (Flader, Susan L.; Callicott, John Baird, eds.) Madison: University of Wisconsin Press.

Miller, Char 2001. Gifford Pinchot: The Making of Modern Environmentalism. Washington: Island Press/Shearwater.

Minteer, Ben; Pyne, Stephen J. 2013. Restoring the narrative of American environmentalism. Restoration Ecology 21(1): 6-11.

Norton, Bryan 2011. What Leopold learned from Darwin and Hadley: Comment on Callicott et al. Environmental Values 20: 7-16.

Ots, Thomas 1991. The neglect of subjective medical data and the cultural construction of pain - A cross-cultural study. In: Sebeok, Thomas; Umiker-Sebeok, Jean, (eds.), Biosemiotics: The Semiotic Web 1991. Berlin: Mouton de Gruyter, 283-300.

Ouspensky, Piotr D. 2004[1912]. Tertium Organon: The Third Canon of Thought, a Key to the Enigmas of the World. (Bragdon, Claude, trans., 1922.) San Diego: The Book Tree.

Peirce, C. S. 2009[1892]. Man's glassy essence. In: Bisanz, Elize (ed.), Charles S. Peirce, The Logic of Interdisiplinarity. Berlin: Akademie Verlag.

Pinchot, Gifford 1905. A Primer of Forestry. Part II-Practical Forestry. (Bulletin 24 Bureau of Forestry.) Washington: U. S. Department of Agriculture.

- 1917. The Training of a Forester. Philadelphia: Lippencott.

Prodi, Giorgio 1989. Biology as natural semiotics. In: Koch, Walter (ed.), For a Semiotics of Emotion. (Beiträge zur Semiotik 4.) Bochum: Brockmeyer.

Ryden, Kent 2008. How could a weed be a book?: Books, ethics, power, and A Sand County Almanac. Interdisciplinary Studies in Literature and the Environment 15(1) (Winter): 1-10.

Sebeok, Thomas A. 1984. Symptome, systematisch und historisch. Zeitschrift für Semiotik 6(1-2): 37-52.

Sebeok, Thomas A.; Danesi, Marcel 2000. The Forms of Meaning: Modeling Systems Theory and Semiotic Analysis. (Approaches to Applied Semiotics 1.) Berlin: Mouton de Gruyter.

Steinsiek, Peter-Michael 2009. Forst- und Holzforschung im "Dritten Reich". (Freiburger Schrift en zur Forst-und Umweltpolitik 18.) Remagen, Germany: Verlag Kessel.

Talmadge, John 1987. Anatomy of a classic. In: Callicott, Baird (ed.), A Companion to A Sand County Almanac: Interpretive and Critical Essays. Madison: University of Wisconsin Press, $110-127$.

Uexküll, Jakob von 1913. Bausteine zu einer biologischen Weltanschauung: Gesammelte Aufsätze von Jakob Baron von Uexküll. (Gross, Felix, ed.) München: F. Bruckmann a. G. 
- 1920. Biologische Briefe an eine Dame. Berlin: Paetel.

- 1921. Umwelt und Innenwelt der Tiere: Zweite Vermehrte und Verbesserte Auflage. Berlin: Springer.

- 1926. Theoretical Biology. (MacKinnon, Doris L., trans.). New York: Harcourt, Brace and Co.

- 1930. Die Lebenslehre. Postdam: Müller \& Kiepenheuer.

- 1980. Kompositionslehre der Natur Biologie als undogmatische Naturwissenschaft. Ausgewählte Schriften. Frankfurt am Main: Ullstein.

- 1982. The Theory of Meaning. (Uexküll, Thure von, trans.) Semiotica 42(1): 25-82.

- 2010[1934]. A Foray into the Worlds of Animals and Humans. (O’Neil, Joseph, trans.) Minneapolis: University of Minnesota Press.

Uexküll, Thure von 1982. Meaning and science in Jakob von Uexküll's concept of biology. Semiotica 42(1): 1-24.

Vietinghoff-Riesch, Arnold Freiherr von 1936a. Naturschutz: Eine nationalpolitische Kulturaufgabe. Berlin, Neudamm: Verlag von J. Neumann.

- 1936b. Die zoologischen Naturdenkmäler. In: Die Naturdenkmäler der Sächs. Oberlausitz. Bautzen: Isis Budissina-Rühl.

- 1940. Forstliche Landschaftsgestaltung. Landschaftsschutz und Landschaftspflege. (Heft 4. Schoenichen, Walther, ed.) Berlin, Neudamm: Verlag von J. Neumann.

- 2002[1952]. Letzter Herr auf Neschwitz: Ein Junker ohne Reue. Limburg an der Lahn: C. A. Starke Verlag. [Rpt. Aus dem Deutschen Adelsarchiv n. F. Vol. 3.]

Weber, Andreas 2003. Natur als Bedeutung: Versuch einer semiotischen Theorie des Lebendigen. (Würzburger Wissenschaftliche Schriften 441.) Würzburg: Verlag Königshausen \& Neumann.

\section{Биосемиотика Альдо Леопольда}

Отвечая на статью Jean-Claude Gens «Uexküll's Kompositionslehre and Leopold's 'land ethic' in dialogue», опубликованную в Sign Systems Studies в 2013 году, автор исследует прямую связь между пониманием экологии Леопольда и теорией умвельта Юкскюля. Связь между ними особенно заметна в описаниях поведения животных, которые Леопольд приводит в первой части своей выдающейся книги «A Sand County Almanac». Именно в этом произведении Леопольд целенаправленно иллюстрирует описанные Юкскюлем биосемиотические процессы, чтобы изменить наше понимание о биотических сообществах как местах семиотических интеракций.

\section{Aldo Leopoldi biosemiootika}

Vastusena Jean-Claude Gensi artiklile "Uexkülli Kompositionslehre ja Leopoldi land ethic dialoogis. Tähenduse mõistest”, mis ilmus ajakirjas Sign Systems Studies aastal 2013, arendatakse käesolevas artiklis edasi otsest seost Aldo Leopoldi ökoloogilise lähenemise ja Jakob von Uexkülli omailmateooria vahel. Side Uexkülli ja Leopoldi vahel on eriti märgatav Leopoldi peateose "A Sand County Almanac" esimeses osas, millest võib leida loomade käitumise kirjeldusi. Just selles teoses illustreerib Leopold biosemiootilisi protsesse, mida oli kirjeldanud Uexküll, ning ta teeb seda sihipäraselt, et kujundada ümber meie arusaama kooslustest kui semiootiliste interaktsioonide toimumispaigast. 